\title{
SOCIAL AND DIETARY FACTORS IN THE SEXUAL MATURATION OF FEMALE MICE
}

\author{
J. G. VANDENBERGH, L. C. DRIGKAMER AND D. R. COLBY \\ Research Division, North Carolina Department of Mental Health, \\ Raleigh, North Carolina
}

(Received 18th March 1971, accepted 6th Fuly 1971)

\begin{abstract}
Summary. At 21 days of age, 144 female albino mice were individually isolated and reared on either $8 \%, 16 \%$ or $24 \%$ protein diets. Within each protein level, mice were exposed to the presence of an adult male, or to male odour, or were reared in isolation. Each female was examined daily for vaginal opening and signs of first oestrus. Body weight and food consumption measures confirmed that body growth was equal in each cell of the design and that mice on low protein diets were not compensating for a low protein diet by consuming more food.

The results showed that, although both dietary protein and the presence of males (or their odour) were significant factors in regulating sexual maturation, social factors contributed $47.3 \%$ and dietary protein levels $4.8 \%$ of the total variance. Accelerated sexual development was not accompanied by accelerated body growth. Thus, the hypothesis that puberty occurs at a critical body weight was not supported by these data. That social stimulation was more effective than protein intake may have relevance to the phenomenon of accelerated sexual maturation in human females.
\end{abstract}

\section{INTRODUCTION}

The social environment both before and after weaning has been shown to influence sexual maturation in female mice (Vandenbergh, 1967, 1969). Groups of six young female mice housed with an adult male attained first oestrus 20 days earlier than young females housed without a male present (Vandenbergh, 1967). Olfaction was identified as the sensory modality involved in the acceleration of puberty when bedding soiled by an adult male mouse and added to a group of young females produced a mean first oestrus comparable to that obtained with the male present (Vandenbergh, 1969).

In addition to pheromonal stimulation from the male, diet has also been shown to affect reproduction and the rate of sexual maturation in rats (Cooper \& Haynes, 1967; Leathem, 1961; Widdowson, Mavor \& McCance, 1964), pigs (Moustgaard, 1959) and mice (Hoag \& Dickie, 1966). In rats, both the development of the reproductive organs and the maintenance of an active reproductive condition are dependent upon diet, particularly the protein component (Leathem, 1961). Female rats given a diet with $18 \%$ casein produced 
litters averaging six to eight young, while rats fed $0 \%$ or $6 \%$ casein diets failed to produce young. Fats have also been implicated in the sexual development and reproductive performance of laboratory mice (Hoag \& Dickie, 1966).

Critical body weight, a factor related to nutrition, has also been suggested as a stimulus to sexual maturation. Kennedy \& Mitra (1963) found that reducing milk intake during the suckling period produced retarded growth and delayed puberty in rats. Puberty was delayed in these animals until they attained approximately the same weight as controls given ample opportunity to suck. Evidence has also been presented by Monteiro \& Falconer (1966) that the attainment of sexual maturity in mice occurs within a specific weight range. These results conflict directly with those obtained by Vandenbergh (1967, 1969). Using mice, Vandenbergh found that females exposed to a male or to male odour matured earlier than mice not exposed to a male, though body weight increased equally in both groups. If body weight in a critical range is causally related to sexual maturation, females exposed to a male should have grown more rapidly than females isolated from male stimuli. Since they did not, it is apparent that male stimulation selectively accelerated sexual maturation without affecting physical development.

The present study was designed to assess the relative importance of social stimulation and protein intake as factors influencing the rate of sexual maturation in female mice. In addition, the growth rates of the mice were measured by changes in body weight to examine further the relationship between a critical body weight and the onset of puberty.

\section{EXPERIMENT 1}

\section{Methods}

A total of 144 closed colony, randomly bred female albino mice, Mus musculus, were weaned at 21 days of age and isolated in $18 \times 28 \times 11 \mathrm{~cm}$ polypropylene cages containing San-i-cel bedding. Each mouse was randomly assigned to one of nine treatment combinations of a $3 \times 3$ factorial experiment. Three levels of social stimulation were used: (1) adult male present; (2) soiled bedding from adult males added daily; and (3) isolated controls. Three levels of dietary protein were tested: $8 \%, 16 \%$ and $24 \%$. Eight mice were tested for each treatment combination during each of two replications of the experiment. The first replication was conducted during May and June, and the second during July and August. To account for any seasonal effect on sexual maturation, time of year was chosen as a blocking factor in the data analysis.

The mice were housed in three separate rooms, all maintained at 68 to $74^{\circ} \mathrm{F}$ and 60 to $75 \%$ relative humidity, with a $12 \mathrm{hr}$ light (01.00 to 13.00 hours), $12 \mathrm{hr}$ dark cycle. Each cage was changed and cleaned every 7 th day. The male bedding stimulus added daily to one-third of the cages consisted of approximately $80 \mathrm{~cm}^{3}$ of soiled bedding from a mixture collected daily from twentyfive cages containing isolated adult males. All males placed in cages with females or used to produce the soiled bedding were of proven fertility. In those cages to which bedding was added daily, $300 \mathrm{~cm}^{3}$ of bedding was removed on the 4 th day of each week to prevent an excessive accumulation. The three diets 
were prepared by the Ralston Purina Company (St Louis, Missouri). Each diet contained equal amounts of fats, vitamins and minerals. The diets were made iso-caloric by adding carbohydrates to the $8 \%$ and $16 \%$ protein diets. Water and the specified diet were supplied freely throughout the study.

Three criteria were used for reproductive maturity: (1) appearance of vaginal introitus; (2) first vaginal oestrus; and (3) first mating. All females were inspected daily between 08.00 and 10.00 hours for vaginal opening. After the appearance of an introitus, a wet-mount vaginal lavage was taken daily from each mouse to determine the age at first oestrus as described by Vandenberg (1967). In cages where a male was present, a vaginal plug was used as an indication of first oestrus and the vaginal lavages were discontinued. In addition, the date of birth of subsequent litters in this treatment group were used to back-date and confirm the date of first oestrus.

TABLE 1

ANALYSIS OF VARIANCE OF THE AGE AT FIRST OESTRUS FOR FEMALE MICE EXPOSED TO THREE TYPES OF SOGIAL STIMULATION AND THREE LEVELS OF DIETARY PROTEIN

\begin{tabular}{l|c|c|c|c}
\hline \multicolumn{1}{c|}{ Source } & d.f. & Mean square & F-value & $\%$ Variance \\
\cline { 2 - 2 } Block & 1 & $61 \cdot 361$ & $6 \cdot 22^{*}$ & $2 \cdot 1$ \\
Social & 2 & $674 \cdot 882$ & $68 \cdot 38^{*}$ & $47 \cdot 3$ \\
Diet & 2 & $68 \cdot 681$ & $6 \cdot 98^{*}$ & $4 \cdot 8$ \\
Block $\times$ social & 2 & $15 \cdot 632$ & $1 \cdot 58$ & - \\
Block $\times$ diet & 2 & $8 \cdot 361$ & $<1$ & - \\
Social $\times$ diet & 4 & $3 \cdot 309$ & $<1$ & - \\
Block $\times$ social $\times$ diet & 4 & $5 \cdot 101$ & $<1$ & \\
Error & 126 & $9 \cdot 869$ & & \\
\hline
\end{tabular}

* Significant at 0.05 level.

Body weights were obtained for each mouse at 21, 28 and 35 days of age and food consumption was measured during the first 2 weeks of the experiment to determine whether mice on low protein diets were compensating by consuming greater quantities of food. Food consumption data were computed in terms of the number of grams of food eaten per gram of mouse per day. Weekly body weight and food consumption measures were analysed separately. Food consumption data could not be collected for young females housed with males.

\section{Results}

The analysis of variance of the data for age at first oestrus indicated that both diet and social stimulation were significant $(P<0.05)$ factors contributing to the onset of sexual maturity (Table 1). Of the two factors, social stimulation accounted for $47.3 \%$, while diet accounted for only $4.8 \%$ of the total variance. None of the interaction terms in the analysis were significant. There were no differences between any of the treatment categories in the age at vaginal opening (Table 2).

When the mean age at first oestrus of females on each diet was calculated without regard to social stimuli, the presence of a male advanced the age of 
TABLE 2

MEAN AGE IN DAYS OF FEMALE MICE AT TWO MEASURES OF SEXUAL MATURITY UNDER THREE CONDITIONS OF SOCIAL STIMULATION AND THREE LEVELS OF DIETARY PROTEIN

\begin{tabular}{|c|c|c|c|c|c|}
\hline Treatment combinations & $\begin{array}{l}\text { No. of } \\
\text { mice }\end{array}$ & \multicolumn{2}{|c|}{$\begin{array}{l}\text { Vaginal opening } \\
\text { Age } \quad \pm S . E .\end{array}$} & \multicolumn{2}{|c|}{ First oestrus } \\
\hline $\begin{array}{l}8 \% \text { protein } \\
\text { o present } \\
\text { o bedding } \\
\text { Control }\end{array}$ & $\begin{array}{l}16 \\
16 \\
16\end{array}$ & $\begin{array}{l}25 \cdot 9 \\
28 \cdot 3 \\
26 \cdot 8\end{array}$ & $\begin{array}{l}0.6 \\
0.6 \\
0.6\end{array}$ & $\begin{array}{l}30 \cdot 4 \\
36 \cdot 2 \\
37.0\end{array}$ & $\begin{array}{l}0.8 \\
1.0 \\
0.9\end{array}$ \\
\hline $\begin{array}{c}16 \% \text { protein } \\
\delta \text { present } \\
\text { o bedding } \\
\text { Control }\end{array}$ & $\begin{array}{l}16 \\
16 \\
16\end{array}$ & $\begin{array}{l}26 \cdot 4 \\
26 \cdot 9 \\
26 \cdot 5\end{array}$ & $\begin{array}{l}0.5 \\
0.7 \\
0.6\end{array}$ & $\begin{array}{l}28 \cdot 8 \\
34 \cdot 2 \\
36 \cdot 3\end{array}$ & $\begin{array}{l}0.4 \\
0.9 \\
0.8\end{array}$ \\
\hline $\begin{array}{c}24 \% \text { protein } \\
\text { o present } \\
\text { o bedding } \\
\text { Control }\end{array}$ & $\begin{array}{l}16 \\
16 \\
16\end{array}$ & $\begin{array}{l}26 \cdot 4 \\
26 \cdot 8 \\
27 \cdot 3\end{array}$ & $\begin{array}{l}0.5 \\
0.4 \\
0.7\end{array}$ & $\begin{array}{l}28.0 \\
33.0 \\
35.5\end{array}$ & $\begin{array}{l}0.6 \\
0.6 \\
1.0\end{array}$ \\
\hline
\end{tabular}

first oestrus to $29 \cdot 1 \pm 0.5$ days of age, or about 8 days after weaning. Mice receiving the soiled bedding reached first oestrus at $34.5 \pm 0.7$ days of age and isolated control mice began cycling at $36 \cdot 3 \pm 0 \cdot 8$ days of age. A Duncan's New Multiple Range test $(\mathrm{Li}, 1964)$ indicated that each of these means for types of social stimulation differed significantly $(P<0.05)$ from one another.

Mean ages at first oestrus computed across the types of social stimulation without regard to diet showed a direct relationship between level of dietary protein and sexual maturation. Mice fed a diet with $8 \%$ protein matured later $(34.5 \pm 0.7$ days of age) than those reared on $16 \%$ protein $(33.1 \pm 0.6$ days of age) or $24 \%$ protein (32.2 \pm 0.6 days of age). A New Multiple Range test on these means showed that the mice on an $8 \%$ protein diet matured significantly $(P<0.05)$ later than those on $16 \%$ or $24 \%$ protein. Means for the latter two protein levels were not significantly different.

TABle 3

MEAN BODY WEIGHT OF FEMALE MICE AT WEEKLY INTERVALS IN EXP. 1

\begin{tabular}{|c|c|c|c|c|}
\hline \multirow[b]{2}{*}{ Treatment combination } & \multirow{2}{*}{$\begin{array}{l}\text { No. of } \\
\text { mice }\end{array}$} & \multicolumn{3}{|c|}{ Mean body weight in $g( \pm 1$ S.E. } \\
\hline & & 21 days & 28 days & 35 days \\
\hline $\begin{array}{l}8 \% \text { protein } \\
\text { o present } \\
\text { o bedding } \\
\text { Control }\end{array}$ & $\begin{array}{l}16 \\
16 \\
16\end{array}$ & $\begin{array}{l}10.5(0.2) \\
10.7(0.3) \\
10.7(0.3)\end{array}$ & $\begin{array}{l}14.3(0.4) \\
13.8(0.3) \\
14.9(0.3)\end{array}$ & $\begin{array}{l}18.2(0.4) \\
16.9(0.2) \\
17.5(0.2)\end{array}$ \\
\hline $\begin{array}{l}16 \% \text { protein } \\
0 \text { present } \\
0^{*} \text { bedding } \\
\text { Control }\end{array}$ & $\begin{array}{l}16 \\
16 \\
16\end{array}$ & $\begin{array}{l}10.2(0.3) \\
10.8(0.3) \\
10.9(0.2)\end{array}$ & $\begin{array}{l}14.6(0.3) \\
14.5(0.4) \\
15 \cdot 0(0.3)\end{array}$ & $\begin{array}{l}18.6(0.5) \\
17.3(0.4) \\
17.6(0.2)\end{array}$ \\
\hline $\begin{array}{l}24 \% \text { protein } \\
\text { ơ present } \\
\text { oे bedding } \\
\text { Control }\end{array}$ & $\begin{array}{l}16 \\
16 \\
16\end{array}$ & $\begin{array}{l}10.5(0.2) \\
10.8(0.4) \\
10.3(0.4)\end{array}$ & $\begin{array}{l}14.7(0.4) \\
14.4(0.4) \\
14.2(0.4)\end{array}$ & $\begin{array}{l}18.3(0.6) \\
17.2(0.3) \\
17.2(0.4)\end{array}$ \\
\hline
\end{tabular}


To confirm the effect of diet, body growth and food consumption were regularly recorded. Weekly weights for the mice in each treatment category are presented in Table 3. Analysis of variance demonstrated that there were no significant weight differences at 21 and 28 days of age. As a consequence of pregnancy, those mice housed with a male were significantly $(P<0.05)$ heavier at 35 days of age than those housed without a male. Subjecting the data on food consumption during Weeks 1 and 2 (Table 4 ) to a three-way analysis of variance failed

TABLE 4

MEAN FOOD GONSUMPTION FOR MICE ON THREE LEVELS OF DIETARY PROTEIN UNDER TWO DIFFERENT TYPES OF SOGIAL STIMULATION

\begin{tabular}{c|cc|cc}
\hline \multirow{2}{*}{$\begin{array}{c}\text { Protein } \\
(\%)\end{array}$} & \multicolumn{2}{|c|}{ Male bedding } & \multicolumn{2}{|c}{ Control } \\
\cline { 2 - 5 } & Week 1 & Week 2 & Week 1 & Week 2 \\
\hline 8 & $0.23(0.02)$ & $0.26(0.02)$ & $0.23(0.01)$ & $0.25(0.02)$ \\
16 & $0.25(0.02)$ & $0.25(0.02)$ & $0.25(0.02)$ & $0.24(0.01)$ \\
24 & $0.26(0.03)$ & $0.25(0.02)$ & $0.25(0.03)$ & $0.25(0.02)$ \\
\hline
\end{tabular}

Values expressed as $\mathrm{g} / \mathrm{g}$ body wt/day ( \pm 1 S.E.).

to reveal any significant main treatment or interaction effects. Thus, the mice in the two treatment groups tested displayed an equal body growth and consumed equal amounts of food.

Female mice housed with males conceived as early as 24 days of age and many produced litters before they were 50 days old. Back-dating from the date of birth showed that all young females producing litters conceived at first oestrus. Only $69 \%$ of the young females reared on $8 \%$ protein produced litters, while $81 \%$ of those on $16 \%$ protein and $100 \%$ of those on $24 \%$ protein bore young (Table 5). Autopsies of mice not producing young showed that implantation had occurred in only one of these mice $(16 \%$ protein). Litter sizes and the average weights of the young at birth were comparable for all three protein diets and compare closely with the performance of the breeders in our laboratory (Table 5). Litters from twenty adult females of the same albino stock in our laboratory (mated first at 60 to 80 days of age and fed a $24 \%$ protein diet) had an average litter size of $8.9 \pm 1.2$ mice and the young weighed $1 \cdot 6 \pm 0.1 \mathrm{~g}$ at birth.

TABLE 5

REPRODUCTIVE PERFORMANCE OF JUVENILE FEMALES EXPOSED TO AN ADULT MALE AND FED THREE DIFFERENT LEVELS OF DIETARY PROTEIN

\begin{tabular}{l|ccc}
\hline & \multicolumn{3}{|c}{ Protein } \\
& $8 \%$ & $16 \%$ & $24 \%$ \\
\hline$\%$ Reproducing & 69 & 81 & 100 \\
Mean litter size (and range) & $10.4(3$ to 13$)$ & $8.2(2$ to 12$)$ & $9.0(4$ to 12$)$ \\
Mean wt of young (g \pm 1 S.E.) & $1.4(0 \cdot 1)$ & $1.6(0.1)$ & $1.6(0.1)$ \\
\hline
\end{tabular}

Sixteen mice were used in each group. 


\section{EXPERIMENT 2}

\section{Methods}

In earlier studies (Vandenbergh, 1967, 1969), groups of six females displayed first oestrus at a mean age of $37 \cdot 1$ days when exposed to a male from the time of weaning or at 42.3 days when exposed to the odour of a male. Groups reared in the absence of male stimuli did not show first oestrus until 57.1 days of age. The results obtained in Exp. 1 of the present study using these same stimuli on isolated rather than grouped females showed mean ages of sexual maturity which were much lower than in the previous investigation. The purpose of this experiment was to repeat, in part, the earlier work with groups of females to determine whether the original results could be repeated.

Thirty weanling female mice were assigned by the split-litter technique to five groups of six mice each. Two groups of six were housed with an adult male of proven fertility; two groups served as 'grouped' controls and the remaining six mice were housed individually. All mice were provided with a $24 \%$ protein diet of Purina Lab Chow. All other experimental conditions and techniques were those used in Exp. 1.

\section{Results}

Those females housed in groups with an adult male present attained first oestrus at a mean age of $35.7 \pm 1.8$ days, while those housed as 'grouped controls' matured at $55 \cdot 1 \pm 1.7$ days of age. The six mice caged individually in this experiment matured at $33 \cdot 2 \pm 1 \cdot 4$ days of age, closely comparable to the control mean age at first oestrus in Exp. 1. The onset of first oestrus in grouped females agrees closely with previous results (Vandenbergh, 1967, 1969) thereby confirming that the techniques and criteria used in Exp. 1 did not differ from those used previously.

\section{DISGUSSION}

The results of this study show that social stimuli from the male provide a strong impetus for the sexual maturation of female mice. Varying levels of protein in the diet also influence sexual maturation but the effect is considerably less pronounced. The absence of an interaction between the two factors investigated, social stimulation and dietary protein, indicate that each acted independently.

First oestrus at a mean age of 28 days (range 24 to 36 days) among females individually exposed to an adult male is the earliest reported onset of puberty in the house mouse. The females that attained first oestrus at such a remarkably early age were functionally mature: they conceived and carried litters to term. Furthermore, the number of young in their litters and the weight of the young at birth equalled that of litters born to older females in the colony. One mouse attained first oestrus and initiated a successful pregnancy at 24 days of age. Such early maturation is equalled or exceeded in few other mammals. Among voles, fertile mating has been reported as early as 13 days of age in Microtus arvalis by Frank (1957). Bailey (1924) reported fertile mating at 25 days of age in an unspecified species of Microtus. More recently, Diamond \& Yanagimachi 
(1970) found that the golden hamster is also a very early breeder. Female golden hamsters used in mating tests attained first oestrus at 26 to 28 days of age.

A comparison of the onset of first oestrus in the current experiment with previously reported ages from this laboratory (Vandenbergh, 1967, 1969) reveals that housing females individually rather than in groups resulted in a much earlier onset of oestrus (Table 6). The effect of male stimulation is strong under both housing conditions but, by housing the females individually, the range of ages at first oestrus is lowered. It is possible that the onset of sexual maturity in females is inhibited by the presence of other females. The relatively early age of sexual maturity displayed by isolated females not exposed to a male indicates that the differences in the two sets of data (Table 6) cannot be due to the more intense male stimulation received by an isolated female. Additional studies are necessary to confirm the inhibitory influence of the presence of females on female sexual maturation and to determine the sensory modalities involved.

TABLE 6

ONSET OF FIRST OESTRUS FOLLOWING MALE STIMULATION IN FEMALE MICE CAGED IN GROUPS OR GAGED SINGLY

\begin{tabular}{|c|c|c|c|c|}
\hline \multirow{3}{*}{ Treatment } & \multirow{3}{*}{$\frac{\begin{array}{c}\text { Previously found } \\
\text { (Vandenbergh, 1969) }\end{array}}{\text { Grouped females }}$} & \multicolumn{3}{|c|}{ Present study } \\
\hline & & \multirow{2}{*}{$\frac{\text { Exp. I }}{\text { Single females }}$} & \multicolumn{2}{|c|}{ Exp. 2} \\
\hline & & & Single females & Grouped females \\
\hline $\begin{array}{l}\text { Male present } \\
\text { Male bedding } \\
\text { No male }\end{array}$ & $\begin{array}{l}39 \cdot 6 \pm 0 \cdot 6 \\
42 \cdot 3 \pm 1 \cdot 0 \\
54 \cdot 6 \pm 2 \cdot 9\end{array}$ & $\begin{array}{l}28 \cdot 0 \pm 0 \cdot 6 \\
33 \cdot 0 \pm 0.6 \\
35.9 \pm 1 \cdot 0\end{array}$ & $\overline{\bar{z}} \overline{\overline{-}}$ & $\begin{array}{l}35 \cdot 7 \pm 1 \cdot 8 \\
55 \cdot 1 \pm 1 \cdot 7\end{array}$ \\
\hline
\end{tabular}

Values expressed as mean age (in days) \pm S.E. at first oestrus.

All females were maintained on the same Purina lab chow, i.e. $24 \%$ protein.

The acceleration of sexual maturation resulting from either male stimulation or increases in dietary protein was not accompanied by a more rapid body growth. The independence of sexual maturation from body growth in the current experiment agrees with previous findings in this laboratory (Vandenbergh, 1967, 1969), with those of Orbach \& Kling (1966) using rats and with Diamond \& Yanagimachi (1970) using hamsters. Furthermore, in a longitudinal study of sixty-six human mothers and their seventy-eight daughters, Damon, Damon, Reid \& Valadian (1969) found that age at menarche was independent of adult stature in both groups. Based on this finding, Damon et al. (1969) suggested that physical growth and sexual maturation might be separate processes.

A number of studies have, however, demonstrated a relationship between body size and sexual maturity. For example, Monteiro \& Falconer (1966) found a close correspondence in age between vaginal opening and the inflexion of the growth curve in mice. Furthermore, the variance in body weight at vaginal opening was less than the variance in body weight at a fixed age. Similarly, Kennedy \& Mitra (1963) showed that rats retarded in growth 
reached sexual maturity at the same weight but at a much later age than rats growing at a rapid rate. From their results, Kennedy \& Mitra (1963) proposed that the hypothalamic control over puberty requires information about the state of somatic development. This proposal stems from the findings of Donovan $\&$ van der Werff ten Bosch (1959), Donovan (1960) and Harris (1961) that the anterior pituitary and ovaries of females are capable of functioning before the onset of puberty and that such function is apparently under inhibitory control by the hypothalamus. Drawing on the above findings, Frisch \& Revelle (1969, 1970) have recently proposed that the attainment of a critical body size in humans leads to an altered metabolic rate which, in turn, alters the ovarianhypothalamic feedback mechanism to produce puberty. This proposal requires re-evaluation in the light of the current study and others cited above which demonstrate an independence of morphological growth and the onset of puberty in animals and humans.

The results of the current study may also provide an interesting animal model to examine the factors associated with the acceleration of puberty in humans noted over the past century or more. Tanner $(1962,1965)$ has documented that menarche has occurred 3 to 4 months earlier each decade during the recent past in the United States of America and Northern Europe. He postulates that the primary stimulus for this change may have been an improvement in diet, especially during infancy (Tanner, 1962, 1965). Alternatively, social stimulation as a result of increased population density, improved means of communication, and other social changes during the past century or more have been suggested as causative agents in the acceleration of puberty in humans (Brown, 1966; Damon et al., 1969). In the current experiment, social stimulation and dietary protein were systematically examined to determine their relative rôles in influencing the onset of puberty in female mice. The finding that both factors independently accelerated puberty but that social stimulation accounted for $47 \%$ and dietary protein for only $5 \%$ of the variance in the age at first oestrus would indicate that social stimulation should be considered a potent stimulus of puberty.

The degree to which these conclusions from data on mice can be transferred to man must be tempered by the knowledge that mice differ considerably from man in the degree to which specific sensory modalities are used to monitor the environment. In mice, social stimuli that influence reproductive biology operate primarily through olfactory mechanisms (Parkes \& Bruce, 1961; Whitten, 1966; Vandenbergh, 1969) whereas a wider range of sensory mechanisms are undoubtedly involved in modifying human reproduction. Thus, social stimulation of a more general nature, e.g. social interaction rate, may be an underlying factor in the acceleration of puberty in humans. As Zacharias \& Wurtman (1969) so clearly point out, the interrelationships between the numerous factors that could influence human sexual maturation pose severe difficulties for the evaluation of each factor's individual contribution.

\section{ACKNOWLEDGMENTS}

This work was supported in part by grants from the United Health Services 
of North Carolina and the U.S. Public Health Service (MH-16870). Dr Lee C. Drickamer is a NSF Post-doctoral Fellow at North Carolina State University on grant GZ-1374 to Dr D. E. Davis.

We are grateful to Dr Albert J. Clawson for assistance in procuring the special diets used and to Dr John Money and Dr Robert D. Lisk for making helpful comments on the manuscript.

\section{REFERENGES}

BAILEy, V. (1924) Breeding, feeding and other life habits of meadow mice (Microtus). F. agric. Res. 27, 523.

Brown, P. E. (1966) The age at menarche. Br. F. prev. soc. Med. 20, 9.

COOPER, K. J. \& HAYNes, N. B. (1967) Modification of the oestrous cycle of the under-fed rat associated with the presence of the male. F. Reprod. Fert. 14, 317.

Damon, A., Damon, S. T., Reid, R. B. \& Valadian, I. (1969) Age at menarche of mothers and daughters, with a note on accuracy of recall. Hum. Biol. 41, 161.

Diamond, M. \& YanaGmach, R. (1970) Reproductive development in the female golden hamster in relation to spontaneous estrus. Biol. Reprod. 2, 223.

Donovan, B. T. (1960) The inhibitory action of the hypothalamus on gonadotrophin secretion. Mem. Soc. Endocr. 9, 1.

Donovan, B. T. \& VAN DER WERFF TEN BOSGH, J. J. (1959) The hypothalamus and sexual maturation in the rat. F. Physiol., Lond. 147, 78.

Frank, F. (1957) The causality of microtine cycles in Germany. F. Wildl. Mgmt, 21, 113.

Frisch, R. E. \& Revelde, R. (1969) The height and weight of adolescent boys and girls at the time of peak velocity of growth in height and weight: longitudinal data. Hum. Biol. 41, 536.

Frisch, R. E. \& REVELLE, R. (1970) Height and weight at menarche and a hypothesis of critical body weights and adolescent events. Science, N.Y. 169, 397.

HARRs, G. W. (1961) The pituitary stalk and ovulation. In: Gontrol of Ovulation, p. 105. Ed. C. Villee. Pergamon Press, London.

HoAg, W. G. \& Dickie, M. M. (1966) Nutrition. In: Biology of the Laboratory Mouse, 2nd edn. Ed. E. L. Green. McGraw-Hill, New York.

Kennedy, G. C. \& MrrRA, J. (1963) Body-weight and food intake as initiating factors for puberty in the rat. F. Physiol., Lond. 166, 408.

LEATHEM, J. H. (1961) Nutritional effects on endocrine secretions. In: Sex and Internal Secretions, p. 666. Ed. W. G. Young. Williams \& Wilkins, Baltimore.

Lr, J. G. R. (1964) Statistical inference. I. Edwards Brothers, Ann Arbor, Michigan.

Monteiro, L. S. \& Falconer, D. S. (1966) Compensatory growth and sexual maturity in mice. Anim. Prod. 8, 179.

MOUSTGAARD, J. (1959) Nutrition and reproduction in domestic animals. In: Reproduction in Domestic Animals. p. 170. Eds. H. H. Cole and P. T. Cupps. Academic Press, New York.

OrBaCH, J. \& KLING, A. (1966) Effect of sensory deprivation on onset of puberty, mating, fertility and gonadal weights in rats. Brain Res., Osaka, 3, 141.

Parkes, A. S. \& BRUCE, H. M. (1961) Olfactory stimuli in mammalian reproduction. Science, N. $Y$. 134, 1049.

Tanner, J. M. (1962) Growth at adolescence, 2nd edn. Blackwell Scientific Publications, Oxford.

TANner, J. M. (1965) The trend towards earlier physical maturation. In: Biological Aspects of Social Problems, p. 40. Eds. J. E. Meade and A. S. Parkes. Oliver \& Boyd, Edinburgh.

VANDENBERGH, J. G. (1967) Effect of the presence of a male on the sexual maturation of female mice. Endocrinology, 81, 345.

VANDENBERGH, J. G. (1969) Male odor accelerates female sexual maturation in mice. Endocrinology, 84, 658.

WhITtEN, W. K. (1966) Pheromones and mammalian reproduction. In: Advances in Reproductive Physiology, Vol. 1, p. 155. Ed. A. McLaren. Academic Press, London.

Widdowson, E. M., Mavor, W. O. \& McCance, R. A. (1964) The effect of undernutrition and rehabilitation on the development of the reproductive organs: rats. F. Endocr. 29, 119.

Zacharias, L. \& Wurtman, R. J. (1969) Age at menarche. Genetic and environmental influences. New Engl. 7. Med. 280, 868. 